\title{
PEMBERDAYAAN KADER PALIATIF KANKER DALAM MERAWAT PASIEN KANKER DI MASYARAKAT DKI JAKARTA
}

\author{
Ni Luh Widani ${ }^{1}$,Dewi Prabawati ${ }^{2}$,Maria Astrid ${ }^{3}$, Fitriana Suprapti ${ }^{4}$ \\ Progam Studi Keperawatan STIK Sint Carolus Jakarta \\ Jl. Salemba Raya No 41 Jakarta Pusat (10440) \\ e-mail: widani24@gmail.com
}

\begin{abstract}
ABSTRAK
Kanker adalah penyakit tidak menular bersifat kronis ditandai adanya pertumbuhan sel abnormal dan pada stadium lanjut tidak bisa disembuhkan. Penderita kanker dapat mengalami masalah fisik, psikologis maupun sosial. Dampak fisik seperti keluhan sesak nafas, luka, pembengkakan, dan stres psikologis. Kondisi yang dialami pasien kanker, membutuhkan perawatan paliatif untuk mencapai hidup yang berkualitas. Perawatan paliatif dengan melibatkan keluarga dalam perawatannya. Pemberdayaan masyarakat melalui kader kesehatan, khususnya kader paliatif dapat membantu keluarga merawat anggota keluarganya yang sakit. Kader paliatif sangat membutuhkan pengetahuan dan ketrampilan dalam merawat pasien kanker dengan permasalahannya. Pelatihan kader paliatif ini dilakukan selama dua periode, setiap periode berlangsung selama dua hari dan dalam praktiknya peserta dibagi menjadi kelompok kecil yang terdiri dari 5-7 orang. Hasil yang didapatkan, peserta semuanya aktif berlatih, mempraktikkan dengan hasil mayoritas baik. Diharapkan kader rutin berlatih, mempraktikkan dan mengajarkan kepada keluarga pasien. Kegiatan ini dapat berlanjut dan dilakukan penyegaran ketrampilan secara rutin.
\end{abstract}

Kata Kunci: Kanker, kader, paliatif, pemberdayaan

\begin{abstract}
Cancer is a chronic non-contagious disease characterized by abnormal cell growth and can not be cured at an advanced stage. Cancer patients can experience physical, psychological and social problems. Physical effects such as complaints of shortness of breath, injury, swelling, and psychological stress. Conditions experienced by cancer patients, requiring palliative care to achieve quality of life. Palliative care by involving the family in their care. Community empowerment through health cadres, especially palliative cadres can help families care for sick family members. Palliative cadres need knowledge and skills in treating cancer patients with their problems. This palliative cadre training is conducted for two periods, each period lasts for two days and in practice participants are divided into small groups of 5-7 people. The results obtained, participants are all actively practicing, practicing with good majority results. It is hoped that cadres regularly practice, practice and teach the patient's family. This activity can be continued and refreshed skills are done routinely.
\end{abstract}

\section{Keywords: Cancer, cadre, palliative, empowerment}

\section{PENDAHULUAN}

Menurut (WHO, 2019) kanker adalah sekelompok penyakit yang dapat terjadi hampir semua organ atau jaringan tubuh akibat pertumbuhan sel-sel abnormal tak terkendali dan dapat menyebar ke organ lain atau metastase dan merupakan penyebab utama kematian akibat kanker. Kanker adalah penyebab utama kedua kematian secara global, diperkirakan sekitar 9,6 juta kematian, atau satu dari enam kematian, pada tahun 2018. Kanker paru-paru, prostat, kolorektal, lambung dan hati adalah jenis kanker yang paling umum pada pria, sedangkan payudara, kanker kolorektal, paru-paru, serviks dan tiroid adalah yang paling umum di antara wanita. Beban kanker terus bertambah secara global, menimbulkan masalah fisik, emosi dan finansial yang luar biasa pada individu, keluarga, komunitas dan sistem kesehatan. Banyak sistem kesehatan di negara-negara berpenghasilan rendah dan menengah paling tidak siap untuk mengelola beban ini, dan sejumlah besar pasien kanker secara global tidak memiliki akses ke diagnosis dan perawatan berkualitas tepat waktu. 
Dalam Peraturan Menteri Kesehatan Republik Indonesia Nomor 71 Tahun 2015 Tentang Penanggulangan Penyakit Tidak Menular, kanker masuk kedalam kelompok penyakit tidak menular, yaitu penyakit yang tidak bisa ditularkan dari orang ke orang yang perkembangannya berjalan perlahan dalam jangka waktu yang panjang (kronis). Kanker masuk ke dalam kategori keganasan pada kelompok penyakit tidak menular (Kemenkes RI, 2015).

Penyakit kaker sebagai penyakit kronis membutuhkan perawatan jangka panjang sehingga membutuhkan perawatan paliatif. Perawatan paliatif adalah bentuk perawatan atau penanganan yang berfokus pada mengurangi beratnya gejala penyakit. Tujuan perawatan paliatif adalah mengurangi dan mencegah penderitaan dan meningkatkan kualitas hidup pasien kanker. Fokus perawatan paliatif adalah mengatasi masalah fisik, support emosional pada pasien dan keluarga menghadapi kondisi terminal dan pembatasan akibat penyakit. Perawatan paliatif memberikan perawatan dengan identifikasi dini mengkaji, mengatasi nyeri, dan perawatan fisik, psikologis, emosional dan distress spiritual sehingga meninggal dengan normal (Lewis S., Dirksen R.S, 2014).

Hasil penelitilan kualitatif dari (Nowels et al., 2016) terhadap dokter dan perawat di pelayanan kesehatan primer didapatkan bahwa perawatan paliatif dibutuhkan untuk mengenali kebutuhan paliatif pasien dengan masalah yang komplek. Dalam pemenuhan kebutuhan pasien dengan menggunakan sumber daya dari masyarakat, sehingga dapat memenuhi kebutuhan pasien. Peneliti menyimpulkan pentingnya melibatkan keluarga dalam perawatan pasien dan pemberdayaan masyarakat untuk mengoordinasikan perawatan di masyarakat.
Kader pemberdayaan masyarakat ini diwujudkan sesuai dengan peraturan perundang-undangan dalam hal ini adalah peraturan Menteri kesehatan nomor 8 tahun 2019 yaitu tentang pemberdayaan masyarakat di bidang kesehatan. Kader kesehatan ini sendiri merupakan setiap orang yang dipilih oleh masyarakat dan dilatih untuk menggerakkan masyarakat dalam berpartisipasi untuk memberdayakan masyarakat terutama dalam bidang kesehatan. Adapun strategi pemberdayaan masyarakat itu sendiri miliputi upaya untuk meningkatkan pengetahuan serta kemampuan masyarakat tentang kanker melaui kader paliatif (Kemenkes RI, 2015).

Dengan kader paliatif yang telah dilakukan pendampingan inilah diharapkan dapat bergerak untuk meningkatkan kesadaran masyarakat untuk mencegah penyakit kanker, serta melakukan deteksi atau pemeriksaan terhadap kanker sejak dini.

Angka kejadian kanker di DKI Jakarta dikutip dari RS. Kanker Dharmais mengenai persentasi kontribusi data berbasis RS berdasarkan domisili pada registrasi kanker nasional (2008 - 2012) berturut turut adalah Jakarta Barat sebesar 14,45 \%, menyusul Jakarta selatan (8,38 \%), kemudian Jakarta Timur $(7,68 \%)$ dan Jakarta utara $(6,72 \%)$ (RS Dharmais, 2012).

YKI (Yayasan Kanker Indonsia) wilayah DKI Jakarta adalah yayasan yang dipimpin oleh istri gubernur. YKI DKI Jakarta, berdiri sejak tanggal 29 September 1986, berperan aktif dalam penyelenggaraan program kesehatan pemerintah DKI Jakarta khususnya dalam menanggulangi kanker serta secara aktif melakukan pembinaan kepada kader paliatif secara rutin setiap tahun. Berdasarkan laporan yang disampaikan oleh kader antara lain, pasien kanker sering tidak mau dirawat di RS dan ingin meninggal bersama keluarga, pasien kanker mengalami 
sesak nafas dan menggunakan oksigen di rumah, tetapi tidak mengerti penggunaannya, ada pasien kanker yang menggunkan selang untuk makan karena tidak mampu membuka mulut dan mengalami perlukaan akibat berbaring lama di tempat tidur. Mendapat laporan para kader, dipandang perlu kader memiliki pengetahuan dasar perawatan pasien kanker yang mengalami perlukaan, menggunakan NGT dan mengurangi nyeri.

Tujuan kegiatan ini adalah (1) meningkatkan kesadaran kader paliatif dalam perannya sebagai kader dalam merawat pasien kanker di masyarakat (2) meningkatkan pengetahuan kader paliatif tentang penyakit kanker dan permasalahannya (3) meningkatkan pengetahuan dan ketrampilan kader paliatif merawat pasien kanker yang mengalami kesulitan makan, mengalami sesak nafas, mengalami perlukaan,

\section{METODE}

Kegiatan berlangsung di Graha YKI DKI Jakarta. Metode pelaksanaan pengabdian yaitu penyuluhan, simulasi dan praktik ketrampilan. Penyuluhan yang diberikan tentang (1) dasar-dasar penyakit kanker paru, kanker usus dan kanker payudara (2) gizi bagi penderita kanker. Ketrampilan yang diajarkan antara lain prosedur merawat luka pasien kanker yang menggunakan colostomy, merawat luka kanker payudara, memberikan makan melalui selang NGT (Naso Gastric Tube), memberikan oksigen dan nebulizer, manajemen nyeri melalui relaksasi dan pencegahan serta perawatan limfedema pada pasien kanker payudara. Kegiatan berlangsung selama dua hari setiap periodenya yaitu pada tanggal 28- 29 dan 30-31 Oktober 2019 dari pukul 08.00 - 17.00 Wib. Peserta pelatihan yaitu kader paliatif kanker yang sudah menjadi kader paliatif lebih dari satu tahun sebanyak 64 kader yang berasal dari lima wilayah di DKI Jakarta. Penyuluhan dilakukan melalui mengalami limfedenitis dan nyeri (4) meningkatkan pengetahuan kader dalam menilai kondisi pasien yang membutuhkan rujukan ke RS. Melalui kegiatan ini, kader memiliki bekal pengetahuan dan ketrampilan dalam mempromosikan pencegahan atau keawaspadaaan penyakit kanker serta mampu merawat pasien kanker di masyarakat yang mengalami masalah fisik maupun psikologis dan selanjutnya mengajarkan ke pasien dan keluarga. Mengingat pasien akan merasa lebih nyaman dalam perawatan di rumah oleh keluarga sehingga keterlibatan keluarga dalam merawat pasien sangat dibutuhkan. Kader paliatif yang telah dilatih, selanjutnya diminta untuk melaporka diri ke puskesmas setempat. Dibawah binaan puskesmas, kader melakukan pendataan pasien kanker yang mengalami masalah fisik.

ceramah dan Tanya jawab. Sedangkan pelatihan, dilakukan melalui simulasi dan praktik secara individu. Peserta periode satu sebanyak 30 peserta dan periode dua sebanyak 34 peserta. Setiap priode kegiatan, peserta dibagi menjadi enam kelompok. Setiap kelompok dibimbing oleh fasilitator yaitu dosen STIK Sint Carolus dan alumni yang menguasai dibidangnya. Kelompok dibuat menjadi enam, agar semua peserta dapat melakukan demonstrasi dengan waktu yang cukup dan sampai trampil. Setelah dinilai mampu, selanjutnya setiap peserta dinilai secara individu ketrampilannya dalam melakukan ke-6 ketrampilan yang diajarkan tersebut dibawah pengawasan fasililator secara ketat. Semua sarana yang digunakan dalam simulasi dan praktik, disiapkan secara lengkap, menyesuaikan dengan kondisi yang akan dihadapi di masyarakat mengalami limfedenitis dan nyeri (4) meningkatkan pengetahuan kader dalam menilai kondisi pasien yang membutuhkan rujukan ke RS. Melalui 
kegiatan ini, kader memiliki bekal pengetahuan dan ketrampilan dalam mempromosikan pencegahan atau keawaspadaaan penyakit kanker serta mampu merawat pasien kanker di masyarakat yang mengalami masalah fisik maupun psikologis dan selanjutnya mengajarkan ke pasien dan keluarga. Mengingat pasien akan merasa lebih

\section{METODE}

Kegiatan berlangsung di Graha YKI DKI Jakarta. Metode pelaksanaan pengabdian yaitu penyuluhan, simulasi dan praktik ketrampilan. Penyuluhan yang diberikan tentang (1) dasar-dasar penyakit kanker paru, kanker usus dan kanker payudara (2) gizi bagi penderita kanker. Ketrampilan yang diajarkan antara lain prosedur merawat luka pasien kanker yang menggunakan colostomy, merawat luka kanker payudara, memberikan makan melalui selang NGT (Naso Gastric Tube), memberikan oksigen dan nebulizer, manajemen nyeri melalui relaksasi dan pencegahan serta perawatan limfedema pada pasien kanker payudara. Kegiatan berlangsung selama dua hari setiap periodenya yaitu pada tanggal 28- 29 dan 30-31 Oktober 2019 dari pukul 08.00 - 17.00 Wib. Peserta pelatihan yaitu kader paliatif kanker yang sudah menjadi kader paliatif lebih dari satu tahun sebanyak 64 kader yang berasal dari lima wilayah di DKI

\section{HASIL DAN PEMBAHASAN}

Kegiatan pengabdian berjalan dengan lancar dan tertib dihadiri oleh 64 kader paliatif. Peserta dilakukan penilaian terkait tiap-tiap prosedur yang Table 1

Gambaran Ketrampilan Peserta Dalam Melakukan Prosedur

\begin{tabular}{lcc}
\hline \multicolumn{1}{c}{ Prosedur } & $\mathrm{n}(64)$ & $\begin{array}{c}\text { prosentase } \\
(\%)\end{array}$ \\
\hline Perawatan Luka & & \\
1. Kurang & 2 & 3 \\
2. Cukup & 30 & 47 \\
3. Baik & 32 & 50 \\
\hline Perawatan & & \\
kolostomi & 4 & 6 \\
\hline
\end{tabular}

nyaman dalam perawatan di rumah oleh keluarga sehingga keterlibatan keluarga dalam merawat pasien sangat dibutuhkan. Kader paliatif yang telah dilatih, selanjutnya diminta untuk melaporka diri ke puskesmas setempat. Dibawah binaan puskesmas, kader melakukan pendataan pasien kanker yang mengalami masalah fisik.

Jakarta. Penyuluhan dilakukan melalui ceramah dan Tanya jawab. Sedangkan pelatihan, dilakukan melalui simulasi dan praktik secara individu. Peserta periode satu sebanyak 30 peserta dan periode dua sebanyak 34 peserta. Setiap priode kegiatan, peserta dibagi menjadi enam kelompok. Setiap kelompok dibimbing oleh fasilitator yaitu dosen STIK Sint Carolus dan alumni yang menguasai dibidangnya. Kelompok dibuat menjadi enam, agar semua peserta dapat melakukan demonstrasi dengan waktu yang cukup dan sampai trampil. Setelah dinilai mampu, selanjutnya setiap peserta dinilai secara individu ketrampilannya dalam melakukan ke-6 ketrampilan yang diajarkan tersebut dibawah pengawasan fasililator secara ketat. Semua sarana yang digunakan dalam simulasi dan praktik, disiapkan secara lengkap, menyesuaikan dengan kondisi yang akan dihadapi di masyarakat.

dilakukan dengan rentang nilai 0-100. Penilaian kurang baik ( nilai $\leq 70$ ), ketrampilan cukup (nilai $>70-79$ ) dan ketrampilan baik (nilai $\geq 80$ ).

\begin{tabular}{lcc}
\hline 1. Kurang & 26 & 40 \\
2. Cukup & 34 & 54 \\
3. Baik & & \\
\hline $\begin{array}{l}\text { Pemberian makan } \\
\text { melalui NGT }\end{array}$ & 4 & 6 \\
1. Kurang & 20 & 31 \\
2. Cukup & 40 & 63 \\
3. Baik & & \\
\hline $\begin{array}{l}\text { Terapi oksigen } \\
\text { dan Nebulezer }\end{array}$ & 0 & 0 \\
1. Kurang & 32 & 50 \\
\hline
\end{tabular}




\begin{tabular}{lcc}
\hline 2. Cukup & 32 & 50 \\
3. Baik & & \\
\hline Tehnik relaksasi & & \\
1. Kurang & 0 & 0 \\
2. Cukup & 21 & 33 \\
3. Baik & 43 & 67 \\
\hline \multicolumn{2}{l}{ Pijat Limfedema } & \\
1. Kurang & 0 & 0 \\
2. Cukup & 7 & 11 \\
3. Baik & 57 & 89 \\
\hline
\end{tabular}

Prosedur Perawatan luka, sebanyak $50 \%$ peserta melakukan dengan baik, peserta sudah mengikuti sesuai tahapan tapi ada 4 orang peserta yang kurang percaya diri. Beberapa pasien kanker mengalami perlukaan akibat kanker sendiri atau akibat tirah baring yang lama. Berdasarkan pernyataan dari kader paliatif bahwa kader tidak mengerti cara merawat luka, demikian juga pasien dan keluarga sehingga luka didiamkan akibatnya menimbulkan infeksi dan bau yang sangat tidak sedap. Luka kanker berbeda dengan luka secara umum, dimana luka kanker adalah luka yang sangat mudah berdarah. Pasien dan keluarga tentunya perlu diajarkan merawat luka kanker dengan benar untuk menghidari risiko terjadinya perdarahan.

Prosedur Perawatan luka kolostomy Pada rawat colostomy, mengikuti langkah-langkah denagn tepat sebanyak 78\%. Pasien dengan kanker usus, kadang dilakukan pemasangan colostomy, keluarga dan pasien perlu mengetahui cara merawat pasien dengan colostomy agar tidak terjadi komplikasi seperti infeksi, diare ataupun konstipasi. Para kader paliatif, juga harus mengerti cara merawat pasien dengan colostomy dengan benar.

Prosedur pemberian makan melalui selang NGT (nasogstric tube), Pada prosedur pemberian makan melalui NGT didapatkan $63 \%$ melakukan dengan dengan nilai baik. Sebagian besar melakukan dengan lancar, ada 20 peserta yang perlu diingatkan terkait prosedur dan ada $6 \%$ peserta kurang cekatan dalam menutup aliran cairan pada selang NGT sehingga udara masuk. Pemberian makan melalui selang naso gastrik bertujuan untuk memenuhi kebutuhan nutrisi pada pasien kanker yang tidak mampu menelan makanan, misalnya pada pasien penurunan kesadaran dan ketidak mampuan menelan. Prinsip yang harus dketahui oleh kader adalah mencegah terjadinya aspirasi akibat pemberian makanan, karena bila terjadi aspirasi, atau masuknya makanan ke saluran nafas dapat berakibat fatal yaitu gangguan pernafasan.

Prosedur penggunaan tabung oksigen dan nebulizer, peserta melakukan dengan penilain cukup dan baik. Pada prosedur terapi nebulezer didapatkan semua peserta mengikuti sesuai dengan tahapan, ada satu orang peserta yang yang perlu diingatkan terkait langkah-langkahnya. Beberapa pasien kanker mengeluh sesak nafas, terutama pasien dengan kanker paru. Studi yang dilakukan oleh (Ramadhaniah et al., 2016) terhadap pasien kanker yang mengalami efusi pleura di RS Darmais didapatkan 58 $(37,4 \%)$ pasien mengalami keluhan sesak nafas. Kader perlu mengetahuai dan mampu menangani pasien dengan keluhan sesak nafas, karena beberapa pasien menggunakan tabung oksigen dirumah. Kader perlu mengajarkan kepada pasien dan keluarga prinsip penting dalam penggunaan tabung oksigen dan merawat pasien sesak nafas dan kapan harus pergi ke pelayanan kesehatan.

Prosedur Manajemen post kemoterapi: relaksasi, peserta aktif mengikuti gerakan yang diajarkan dan mau mencoba dan semangat belajar sebanyak $67 \%$ melakukan dengan nilai baik. Pasien kanker sering mengeluh nyeri akiabt proses penyakitnya. Nyeri adalah gejala umum yang dialami oleh pasien kanker. Penelitian yang dilakukan oleh (Nadeem Ramsha,et.al , 2018) pada 
pasien kanker stadium lanjut yang menerima perawatan paliatif sebanyak 180 pasien, dalam usia 18 - 70 tahun dengan stadium 3 dan 4 di RS Mayo Hospital Lahore didapatkan 68,89\% pasien tidak dilakukan pengkajian dan penanganan nyeri yang edekuat dan tidak tercatat dalam pengkajian manajemen nyeri yang efektif untuk pasien onkologi, sehingga sangat dibutuhkan adanya pengkajian dan manajemen nyeri pada pasien kanker. Pasien dan keluarga harus mengetahuai manajemen untuk mengurangi nyeri, karena kadang-kadang pemberian analgetik kurang berpengaruh bila pasien mengalami nyeri kronis. Maka manajemen nonfarmakologi dapat diajarkan kepada pasien. Penelitian oleh (Natosba et al., 2019) terhadap 33 orang responden kanker serviks di RSUP dr.Mohammad Hoesin Palembang Peneliti menemukan sebagian responden penelitian terlihat menunjukkan respon meringis dan bahkan sampai menangis saat nyeri sedang berlangsung. Responden penelitian tidak dapat berfokus pada hal lain pada saat serangan nyeri sedang berlangsung. Terapi komplementer PMR Progressive Muscle Relaxation dan Hypnotherapy perlu dilakukan sebagai terapi non farmakologi yang terbukti dapat menurunkan nyeri dan kecemasan. Berdasarkan 10 (sepuluh) jurnal yang telah di analisis bahwa self pain management berpengaruh terhadap penurunan intensitas dan peningkatan pengetahuan dalam mengelola nyeri pasien kanker. Self Pain Management melalui telehealth, kunjungan rumah, psikoedukasi klinik mampu menurunkan nyeri secara signifikan. Intervensi metode Self Pain Management memberikan informasi kepada pasien dalam melakukan perawatan diri terkait gejala dan efek samping pengobatan seperti menilai gejala mereka sendiri dan menggunakan pengobatan yang tepat, metode Self Pain Management memiliki tiga strategi utama yaitu pemberian informasi terkait nyeri dan cara mengatasi, melatih keterampilan dalam mengenali nyeri, menggunakan obat, dan pendampingan serta monitoring oleh perawat.

Prosedur Pencegahan limfedenitis, melalui pijat limfedema, peserta antusias mengikuti, sebanyak 89\% melakukan dengan baik. Prinsip dalam prosedur ini yang harus ditekankan yaitu menghidari penekanan, jadi hanya dengan sentuhan lembut. Pasien kanker payudara berisiko mengalami infeksi limfeditis akibat proses penyakit, akibat prosedur pembedahan dan infeksi. Kondisi ini akan menyebabkan rasa tidak nyaman dan mengurangi kualitas hidupnya. Sehingga pasien perlu diajarkan tindakan atau manajemen bila mengalami pembengkakan di lengan akibat limfedenitis. Intervensi yang dapat diajarkan adalah dengan pijat limfedema.

Data registrasi kematian di Inggis dari 570.000 kematian di negaranegara berpenghasilan tinggi, $69 \%-82 \%$ dari mereka yang meninggal membutuhkan perawatan paliatif (Murtagh et al., 2014). Kader paliatif diharapkan membantu dan mengajarkan keluarga dalam merawat pasien kanker dengan berbagai keluhan. Akibat keterbatasan finansial, keterbatasan fisik, kadang pasien tidak mampu datang ke RS sehingga sering terjadi pembiaran kondisi yang dapat mengancam. PCHN (Paliatif Community Health Nursing) merupakan paket pelayanan perawatan kesehatan masyarakat (perkesmas)perawatan paliatif yang diberikan kepada keluarga dan penderita kanker di rumah, yang berfokus pada kegiatan promotif dan preventif. Penelitian (Ulfiana et al., 2018) dengan melakukan intervensi PCHN terhadap 
peningkatan kemandirian keluarga dalam perawatan penderita kanker di rumah terhadap 7 keluarga penderita kanker pascaperawatan di wilayah kerja Puskesmas Mulyorejo, Surabaya. Diapatkan ada perbedaan tingkat kemandirian keluarga penderita kanker sebelum dan sesudah PCHN ( $p=0,025)$.

\section{KESIMPULAN}

Pasien kanker membutuhkan perawatan paliatif. Kualitas hidup pasien kanker meningkat dengan perawatan paliatif yang dilakukan oleh keluarga, hal ini dapat berhubungan dengan aspek emosional dan sosial yang dikembangkan sebagian besar untuk meningkatkan keterlibatan pengasuh keluarga dalam perawatan pasien paliatif, dengan adanya kebersamaan dengan orang terdekat (Kristanti et al., 2017).

Kelebihan dalam kegiatan ini adalah semua peserta sudah pernah berhadapan dan merawat pasien kanker di masyarakat, sehingga permasalahan yang dihadapi dapat didiskusikan. Dalam pelaksanaannya kegiatan pelatihan dilakukan selama dua hari untuk satu kegiatan, dengan harapan

\section{UCAPAN TERIMA KASIH}

Penulis mengucapkan terima kasih kepada YKI DKI Jakarta yang

\section{DAFTAR PUSTAKA}

Kemenkes RI. (2015). Peraturan Menteri Kesehatan Republik Indonesia No 8 tahun 2019 (Vol. 6, Issue https://doi.org/10.1109/MTAS.200 4.1371634

Kristanti, M. S., Setiyarini, S., \& Effendy, C. (2017). Enhancing the quality of life for palliative care cancer patients in Indonesia
Peneliti menyimpulkan PCHN dapat dikembangkan sebagai salah satu metode untuk meningkatkan pelayanan paliatif di masyarakat . Keluarga penderita kanker diharapkan melaksanakan tugas keluarga dalam kesehatan untuk mencapai kemandirian dalam perawatan kanker di rumah

peserta tidak terlalu banyak dalam satu kegiatan agar dapat dievaluasi secara ketat dan dalam praktiknya kader dibagi dalam kelompok kecil yaitu enam kelumpok dimana satu kelompok terdiri dari 5- 7 orang, sehingga semua kader dapat melakukan dengan waktu yang cukup banyak, kemudian dilakukan penilaian terkait ketrampilan tersebut. Hasil penilaian menunjukkan semua peserta aktif berlatih, antusias dan mayoritas mampu melakukan dengan nilai baik. Kekurangannya, belum bisa menunjukkan kondisi nyata pasien dengan lupa atau pasien dengan colostomy. Pelatihan selanjutnya, bisa melakukan kujungan rumah kepaa pasien yang mengalami perlukaan dan memberikan perawatan secara langsung pada pasien

telah memberi dukungan financial terhadap pengabdian ini dan para dosen STIK Sint Carolus dan alumni STIK Sint Carolus sebagai fasilitator pelatihan

through family caregivers: A pilot study of basic skills training. BMC Palliative Care, 16(1), 1-7. https://doi.org/10.1186/s12904016-0178-4

Lewis S., Dirksen R.S, H. M. M. B. L. (2014). Medical Surgical Nursing Assessment and Management of Clinical Problem (Ninth Edit).

Murtagh, F. E. M., Bausewein, C., Verne, J., Iris Groeneveld, E., Kaloki, Y. E., \& Higginson, I. J. (2014). How many people need 
palliative care? A study developing and comparing methods for population-based estimates. Palliative Medicine, 28(1), 49-58. https://doi.org/10.1177/026921631 3489367

Nadeem Ramsha, Qamar Samina, Khokhar Abbas, Abid Masyam, Z. R. (2018). Palliative Care; Frequency of Inadequate Pain Assessment in Advanced. The Professional MEdical Journal, 25(12), 1910-1914. https://doi.org/10.29309/TPMJ/18. 4753

Natosba, J., Rahmania, E. N., \& Lestari, S. A. (2019). Studi Deskriptif: Pengaruh Progressive Muscle Relaxation Dan Hypnotherapy Terhadap Nyeri Dan Kecemasan Pasien Kanker Serviks Descriptive Study: the Effect of Progressive Muscle Relaxation and Hypnotherapy on Pain and Anxiety of Cervical Cancer Patients.

Nowels, D., Jones, J., Nowels, C. T., \& Matlock, D. (2016). Perspectives of primary care providers toward palliative care for their patients. Journal of the American Board of Family Medicine, 29(6), 748-758. https://doi.org/10.3122/jabfm.2016 .06 .160054

Ramadhaniah, F., Mulawarman, A., Suzanna, E., \& Andalucia, L. R. (2016). Gambaran Kanker Paru Karsinoma Bukan Sel Kecil dengan Efusi Pleura Characteristic of Non Small Cell Lung Cancer with Pleural Efusion. Jurnal Respirologi Indonesia, 36(2), 60-66.

RS Dharmais. (2012). Registrasi Kanker Nasional.

Ulfiana, E., Has, E. M. M., \& Rachmawati, P. D. (2018). Pengembangan Palliative Community Health Nursing (Pchn) Untuk Meningkatkan Kemandirian Keluarga Dalam Merawat Penderita Kanker Di Rumah. Jurnal Ners, 8, 309316.https://books.google.com/book ?id=IXnOesumg Mk\&pgis=1

WHO. (2019). Cancer. 